\title{
Feasibility Study: Assessing the Efficacy and Social Acceptability of Using Dental Hygiene-Therapists as Front-Line Clinicians
}

Macey, Richard; Glenny, Anne-Marie; Brocklehurst, Paul

\section{British Dental Journal}

DOI:

10.1038/sj.bdj.2016.913

Published: 09/12/2016

Peer reviewed version

Cyswllt i'r cyhoeddiad / Link to publication

Dyfyniad o'r fersiwn a gyhoeddwyd / Citation for published version (APA):

Macey, R., Glenny, A-M., \& Brocklehurst, P. (2016). Feasibility Study: Assessing the Efficacy and Social Acceptability of Using Dental Hygiene-Therapists as Front-Line Clinicians. British Dental Journal, 221(11), 717-721. https://doi.org/10.1038/sj.bdj.2016.913

\footnotetext{
Hawliau Cyffredinol / General rights

Copyright and moral rights for the publications made accessible in the public portal are retained by the authors and/or other copyright owners and it is a condition of accessing publications that users recognise and abide by the legal requirements associated with these rights.

- Users may download and print one copy of any publication from the public portal for the purpose of private study or research.

- You may not further distribute the material or use it for any profit-making activity or commercial gain

- You may freely distribute the URL identifying the publication in the public portal ?
}

Take down policy

If you believe that this document breaches copyright please contact us providing details, and we will remove access to the work immediately and investigate your claim. 


\section{Feasibility Study: Assessing the Efficacy and Social Acceptability of Using Dental Hygiene-Therapists as Front-Line Clinicians}

Richard Macey, Anne-Marie Glenny, Paul Brocklehurst

\section{Abstract \\ Background}

The oral health of the adult population has been improving in the United Kingdom decade upon decade. Over half of dental service activity in the National Health Service (NHS) is limited to a "check-up" without any further treatment. This raises a question as to whether "check-ups" could be provided by Dental Hygiene-Therapists, rather than General Dental Practitioners. The aim of this study was to assess the feasibility of a definitive trial to evaluate the costs and effects of using Dental-Hygiene-Therapists to undertake the "checkup".

\section{Methods/Design}

Adult NHS patients were randomised into three arms in two dental practices: patients who only saw Dental Hygiene-Therapists for a "check-up", those that saw the General Dental Practitioner and Dental Hygiene-Therapist alternatively and a control, where patients only saw the General Dental Practitioner for their "check-up". The study ran for 15 months. The primary outcome measures of the study were patient recruitment, retention and fidelity. A parallel and embedded qualitative study was undertaken which recorded the views of participating patients to determine the social acceptability of the intervention.

\section{Results}

Sixty patients participated in the study. The initial recruitment rate for the study was $33.7 \%$. This figure increased to over $82.1 \%$ when telephone calls or face-to-face recruitment was utilised. The retention rates were $60.0 \%$ for both the Dental Hygiene-Therapist only group and the alternate General Dental Practitioner and Dental Hygiene-Therapist group, compared to $70.0 \%$ for the General Dental Practitioner only group. Fifteen patients were interviewed in the qualitative study and supported a team approach to the provision of "check-ups" in the NHS.

\section{Conclusion}


This study demonstrates the feasibility of a definitive trial to evaluate the costs and effects of using Dental-Hygiene-Therapists to undertake the "check-up".

\section{Background}

For state-funded health systems, it is important that the clinical work-force has "the right number of people with the right skills in the right place at the right time to provide the right services to the right people" (1). One method of achieving this is to fully utilise all the members of the health-care team and explore new potential roles to reflect changes in population need.

The oral health of the adult population in the United Kingdom (UK) has been improving decade upon decade (2). The levels of both dental caries and periodontal disease have fallen and ninety percent of the adult population now have more than twenty one teeth (3). Of the $£ 3-4 B n$ spent annually on NHS Dentistry, $95 \%$ of these costs arise from routine care provided by General Dental Practitioner's (GDP) in "high-street" dental practices (4). Over fifty percent of this NHS activity relates to the GDP undertaking a "check-up" without the patient requiring any further treatment (4). As population health improves further, it is likely that more regularly attending adult patients will only require a "check-up" in the future $(5,6)$. This raises a question about the rationale of using the most expensive resource (the GDP) to undertake this task, when other members of the dental team could be utilised safely e.g. the Dental Hygiene-Therapists (H-T) (7-16).

Such an approach has the potential to release resources at a practice level and also increase the capacity to care for those who currently don't access services, thereby reducing the efficiency, cost-effectiveness and equity of NHS service provision $(5,17)$. H-Ts also adopt a more preventive approach, when compared to many GDPs, as their clinical training focuses on prevention rather than surgical intervention $(8,18,19)$. However, although intuitive, using a less expensive resource to undertake a clinical task may not always result in a cost saving (20). Less experienced staff may take more time to reach a diagnosis and see fewer patients per session. They may also use more consumables or over-refer (19). A further substantive barrier to using $\mathrm{H}-\mathrm{Ts}$ as a front-line clinician, is the social and professional acceptability of the model for patients and GDPs. Although the literature would suggest that the use of $\mathrm{H}-\mathrm{Ts}$ is accepted by the majority of the population (21-24), this relates to traditional roles of utilisation. Other surveys have identified substantial negativity (25) and a lack of understanding of $\mathrm{H}$-Ts roles and responsibilities (26-28). The evidence from medicine suggests that patients quickly adapt to new roles within primary health care 
$(20,29)$, but regular adult dental attenders may react differently should the $\mathrm{H}$-Ts adopt a more front-line role (30).

To test the hypothesis that $\mathrm{H}$-Ts could offer a cost-effective and acceptable alternative to GDPs when undertaking the "check-up", an experimental design is required, such as a pragmatic randomised controlled trial. This was recommended by the Galloway review and again reiterated by Turner et al. $(8,19,31)$. The aim of a definitive trial in this context would be to determine whether the standard of oral health differs over the trial period when patients see a H-T compared to a GDP for their regular dental "check-up" i.e. evaluate both the costs and effects of using the H-T as a front-line clinician. However, many of the key parameters are unknown, for example, retention and recruitment rates and treatment fidelity.

The aim of this study was to assess the feasibility of undertaking a full trial; estimate retention, recruitment, treatment fidelity and determine the acceptability of the intervention to patients and clinicians alike. 


\section{Methods}

The study was approved by West of Scotland Research Ethics Committee under a proportionate review (14/WS/1047).

\section{Participants and setting}

The eligibility criteria of the feasibility study were designed to ensure that participants were regularly attending adult patients, representative of the group that consume the bulk of NHS resources for the "check-up" $(17,32)$. The inclusion criteria for practices were:

- At least half of regularly attending adult patients seen within the NHS;

- Employment of a H-T with at least two years of service;

- Support of a practice manager.

Patient inclusion criteria were:

- NHS patient;

- Adult patient of at least 18 years of age;

- Regular attender (attended for at least one check-up within the previous two years);

- Dentate or partially dentate;

- Asymptomatic on presentation to the first "check-up".

Edentate and patients presenting with pain or problems were excluded.

\section{Sample size}

The power calculation accounted for the lowest expected effect in the outcome measures utilised. A sample size of 60 provided sufficient power to estimate a recruitment rate of $50 \%$ to within a one-sided $95 \%$ confidence interval of $10.62 \%$ (33).

\section{Participant recruitment}

An introductory letter and participant information sheet was issued as part of the standard dental "check-up" process and was followed up by a telephone call, one week later. If verbal consent was provided then the patient was given an appointment to attend a designated clinical session. Upon attendance informed written consent was obtained by a trained member of the research team. Concealed randomisation was performed by the research team, to one of the three research arms: (i) $\mathrm{H}-\mathrm{T}$ only, (ii) GDP then $\mathrm{H}-\mathrm{T}$, and (iii) GDP only. 
Following written consent, the patients attended their routine dental "check-up" appointment and completed the Study Record Sheet (SRS). If the patient was healthy and no further treatment was required, then the patient returned to the recall list, to be contacted again in six months using a modified recall letter and follow-up telephone calls. Where treatment was deemed necessary by the front-line clinician, patients were referred to the relevant practitioner, based on their Scope of Practice (34). The study ran for 15 months.

\section{Outcome measures}

The primary outcomes for the study were:

- Recruitment rate;

- Retention rate;

- Treatment fidelity.

Secondary outcomes related to pragmatic measures of oral health:

- Proportion of teeth with at least one site that bleeds on probing (BoP);

- Proportion of teeth with at least one site that is above $3.5 \mathrm{~mm}$ (partial disappearance of the black band of the Basic Periodontal Examination (BPE) probe) (35);

- Proportion of teeth with at least one site per tooth that had visible plaque;

- Proportion of teeth with active caries, defined as frank cavitation into at least the enamel (white spot lesions were also noted on the SRS).

\section{Qualitative interviews}

In parallel to the feasibility study, an opportunistic sample of patients was recruited for semistructured interviews. These were recorded digitally then transcribed verbatim for thematic analysis. The principle of saturation was used to determine the final number of interviews undertaken (36). To facilitate triangulation, the transcripts were coded separately by different members of the research team $(37,38)$. Constant comparative analysis was utilised to allow for any unexpected topics to be fed back into the topic guide and inform future interviews. 


\section{Results}

\section{Recruitment}

Two practices were identified that had participated in previous research (39) and each successfully recruited 30 patients. The overall recruitment rate was $33.7 \%$ however the method of recruitment had an influence (Table 1). 110 letters were distributed to practice patients and only resulted in three recruited patients $(2.7 \%)$. The second method utilised follow-up telephone calls and reported a recruitment rate of $85.0 \%$. The third method was the use of face-to-face invitation. One practice, recruited 23 of its 30 patients using this method (recruitment rate of $82.1 \%$ ), the other practice did not utilise face to face recruitment. The overall recruitment rate through direct contact with patients, either by telephone or by a face-to-face invitation was $83.8 \%(57 / 68)$.

\section{Retention}

Over the 15 month period, three recall appointment cycles were employed by the feasibility study. Thirteen patients failed to attend the second round of routine examinations $(78.3 \%)$ and a further nine were lost to the final round of routine examinations $(63.3 \%)$, with very little difference between the two practices (Table 2). The reasons given were difficult to ascertain as 13 patients did not respond to any follow-up letters or telephone calls. Four patients were blocked by the practice for routinely failing to attend appointments, two patients left the area and one had become too ill to attend the dental practice.

\section{Fidelity}

Treatment fidelity was at a consistently high level across all three rounds of "check-up" appointments. Overall, this was $94.7 \%$ for the study. At baseline, all SRSs were completed in full. In the second round of "check-up" appointments only one record sheet was missing data in the BoP, plaque and pocketing section (Table 3 ). In the final round of "check-up" appointments, only two forms were not completed in full.

\section{Clinical Outcomes}

Table 4 presents the proportions of sites with BoP, plaque, pocketing and caries at each of the appointment sessions. The proportion of sites with BoP was $46.7 \%, 14.5 \%$ and $32.1 \%$ in Arms 1, 2 and 3 respectively; plaque $68.2 \%, 43.7 \%$ and $60.9 \%$, pocketing $23.0 \%, 10.9 \%$ and $24.3 \%$; caries $1.7 \%, 1.4 \%$ and 1.9 . 
Of the total sample of 60,15 patients were interviewed before no new themes emerged. Patients had a mean age of 52.5 years and $60.0 \%$ of interviewees were female. $47.0 \%$ of interviewed patients were from the "H-T only" group, the remainder being split equally between the "alternate" and "GDP only" group. Patients were interviewed immediately following the routine examination at "check-up" appointments two or three. The transcripts were grouped into 13 codes and three emerging themes (Table 5). Patients showed a belief in the H-T's skill level and an embedded trust in the health care system to ensure patient safety. There was also an acceptance of H-Ts when performing the dental check-up and patients appreciated the alternate pathway, particularly the potential for a second opinion. In contrast, two patients showed a strong preference for continuity care with either GDP or H-T. The majority of patients expressed the view that the same payment should be made irrespective of who conducted the check-up.

\subsection{Discussion}

The aim of this study was to assess the feasibility of a definitive trial to evaluate the costs and effects of using H-Ts to undertake the "check-up" and the results appeared to be positive. When the recruitment strategy employed direct contact (telephone or face-to-face), the recruitment rate was $83.8 \%$. This is consistent with the literature $(40,41)$. Failure to attend for a routine "check-up" appointment is a common concern for all "high-street" NHS dental practices (42), so retention was always considered to be more of a challenge. Many adult NHS patients on a six-monthly recall strategy for their "check-up" appointment will fail to respond to reminders and commonly attend between six and twelve months after their previous appointment (42). This is particularly common in areas of social deprivation. Due to constraints on the time frame of this feasibility study, deadlines for the second and third examination where imposed and a failure to attend at this point was thereby classed as a loss-to-follow-up. Despite this the retention rate was $63.3 \%$, which suggests that a definitive trial is possible. It is anticipated that the longer timeframe in a full trial would allow for slippage from the six-monthly routine "check-up" appointment cycle.

The strength of this study was this it offered a unique opportunity to assess the recruitment, retention, fidelity and acceptance of patients when using $\mathrm{H}-\mathrm{Ts}$ to undertake the routine "check-up". Existing evidence suggests that $\mathrm{H}$-Ts are socially acceptable, but the use of $\mathrm{H}$ Ts as a "front-line" clinician undertaking routine "check-ups" has not been explored (21, 23$25,43)$. The results from this study are encouraging, as undertaking the routine "check-up" has traditionally been seen as the preserve of the GDP.

Overall, the views of patients were positive. Points of particular interest were that the majority felt that the same amount should be charged for a routine "check-up" with a H-T, 
compared to a GDP. There was a consensus that, if given the option, patients would prefer to have continuity of care. However, there was also an understanding that this may not be feasible within the confines of a state-funded system.

Saturation was achieved after a relatively low number of patient interviews. The reason for this could be that the practices involved in this study have utilised $\mathrm{H}$-Ts for many years, with both practices allowing $\mathrm{H}$-Ts to complete restorations which is more unusual nationally (6, 18). Despite this, the evidence gathered supports the findings relating to patient acceptance of $\mathrm{H}$-Ts within the existing literature $(21,23-25,44)$. Furthermore it confirms the acceptability of $\mathrm{H}-\mathrm{Ts}$ when completing tasks previously undertaken by GDPs.

\section{Conclusion}

This study highlights the potential for greater utilisation of H-Ts in the routine dental "checkup". A randomised control trial to fully investigate the potential of H-Ts to complete the routine examination appears feasible. 


\section{References}

1. Birch S, Kephart G, Murphy GT, O'Brien-Pallas L, Alder R, MacKenzie A. Health Human Resources Planning and the Production of Health: Development of an Extended Analytical Framework for Needs-Based Health Human Resources Planning. Journal of Public Health Management and Practice. 2009:S56-S61.

2. White DA, Tsakos G, Pitts NB, Fuller E, Douglas GVA, Murray JJ, et al. Adult Dental Health Survey 2009: common oral health conditions and their impact on the population. British Dental Journal. 2012;213(11):567-72.

3. Steele J, Treasure E, O'Sullivan I, Morris J, Murray J. Adult Dental Health Survey 2009: transformations in British oral health 1968-2009. British Dental Journal. 2012;213(10):523-7. 4. Health and Social Care Information Centre. NHS Dental Statistics for England - 2013-14. http://wwwhscicgovuk/catalogue/PUB14738/nhs-dent-stat-eng-13-14-reppdf. 2014;Accessed 23 February 2015.

5. Watt RG, Steele JG, Treasure ET, White DA, Pitts NB, Murray JJ. Adult Dental Health Survey 2009: implications of findings for clinical practice and oral health policy. British Dental Journal. 2013;214(2):71-5.

6. Godson JH, Williams SA, Csikar JI, Bradley S, Rowbotham JS. Dental therapy in the United Kingdom: part 2. A survey of reported working practices. British Dental Journal. 2009;207(9):417-23. 7. Turner S, Tripathee S, MacGillivray S. Direct access to DCPs: what are the potential risks and benefits? British Dental Journal. 2013;215(11):577-82.

8. Galloway J, Gorham J, M L, Richards D, Russell D, Russell I, et al. The professionals complementary to dentistry: systematic review and synthesis. 2003.

9. Nash DA, Friedman JW, Kardos TB, Kardos RL, Schwarz E, Satur J, et al. Dental therapists: a global perspective. International Dental Journal. 2008;58(2):61-70.

10. Brocklehurst P, Ashley J, Walsh T, Tickle M. Relative performance of different dental professional groups in screening for occlusal caries. Community Dentistry and Oral Epidemiology. 2012;40(3):239-46.

11. Hopcraft MS, Morgan MV, Satur JG, Wright FAC. Utilizing dental hygienists to undertake dental examination and referral in residential aged care facilities. Community Dentistry and Oral Epidemiology. 2011;39(4):378-84.

12. Kwan SYL, Prendergast MJ. The use of clinical dental auxiliaries as examiners in caries prevalence surveys in the United Kingdom: a feasibility study. Community Dentistry and Oral Epidemiology. 1998;26(3):194-200.

13. Brocklehurst P, Kujan O, Glenny AM, Oliver R, Sloan P, Ogden G, et al. Screening programmes for the early detection and prevention of oral cancer. The Cochrane Library. 2010;11.

14. Macey R, Walsh T, Glenny A-M, Worthington H, Tickle M, Ashley J, et al. Protocol for diagnostic test accuracy study: the efficacy of screening for common dental diseases by Dental Care Professionals. BMC Oral Health. 2013;13(1):45.

15. Evans C, Chestnutt IG, Chadwick BL. The potential for delegation of clinical care in general dental practice. British Dental Journal. 2007;203(12):695-9.

16. Tickle M, McDonald R, Franklin J, Aggarwal VR, Milsom K, Reeves D. Paying for the wrong kind of performance? Financial incentives and behaviour changes in National Health Service dentistry 1992-2009. Community Dentistry and Oral Epidemiology. 2011;39(5):465-73.

17. Godson JH, Williams SA. Inequalities in health and oral health in the UK. Dental Update. 2008;35(4):243-50.

18. Dyer TA, Brocklehurst P, Glenny AM, Davies L, Tickle M, Issac A, et al. Dental auxiliaries for dental care traditionally provided by dentists. The Cochrane Library. 2014;8.

19. Turner S, Tripathee S, MacGillivray S. Benefits and risks of direct access to treatment by dental care professionals: A rapid evidence review. Final Report to the General Dental Council. 2012. 20. Sibbald B, Shen J, McBride A. Changing the skill-mix of the health care workforce. Journal of Health Services Research \& Policy. 2004;9(suppl 1):28-38. 
21. Dyer TA, Robinson PG. The acceptability of care provided by dental auxiliaries: A systematic review. The Journal of the American Dental Association. 2015.

22. Nilchian F, Rodd HD, Robinson PG. Influences on dentists' decisions to refer paediatric patients to dental hygienists and therapists for fissure sealants: a qualitative approach. British Dental Journal. 2009;207(7):E13; discussion 326-7.

23. Dyer TA, Humphris G, Robinson PG. Public awareness and social acceptability of dental therapists. British Dental Journal. 2010;208(1):16-7.

24. Dyer TA, Robinson PG. Exploring the social acceptability of skill-mix in dentistry. Int Dent J. 2008;58(4):173-80.

25. Ross $M$, Ibbetson $R$, Turner $S$. The acceptability of dually-qualified dental hygienist-therapists to general dental practitioners in South-East Scotland. British Dental Journal. 2007;202(3):E8-E.

26. Gallagher J, Wright D. General dental practitioners' knowledge of and attitudes towards the employment of dental therapists in general practice. British Dental Journal. 2003;194(1):37-41.

27. Ward $P$. The changing skill mix-experiences on the introduction of the dental therapist into general dental practice. British Dental Journal. 2006;200(4):193-7.

28. Jones $G$, Devalia R, Hunter L. Attitudes of general dental practitioners in Wales towards employing dental hygienist-therapists. British Dental Journal. 2007;203(9):E19-E.

29. Laurent M, Reeves D, Hermens R, Braspenning J, Grol R, Sibbald B. Substitution of doctors by nurses in primary care. The Cochrane Library. 2009;4.

30. Morris AJ, Steele J, White DA. Adult dental health survey: The oral cleanliness and periodontal health of UK adults in 1998. British Dental Journal. 2001;191(4):186-92.

31. Innes NP, Evans DJ. Evidence of improved access to dental care with direct access arrangements. Evidence-Based Dentistry. 2013;14(2):36-7.

32. Milsom KM, Jones $C$, Kearney-Mitchell $P$, Tickle $M$. A comparative needs assessment of the dental health of adults attending dental access centres and general dental practices in Halton \& St Helens and Warrington PCTs 2007. British Dental Journal. 2009;206(5):257-61.

33. Lancaster GA, Dodd S, Williamson PR. Design and analysis of pilot studies: recommendations for good practice. Journal of Evaluation in Clinical Practice. 2004;10(2):307-12.

34. GDC. Scope of Practice. http://wwwgdc-

ukorg/Dentalprofessionals/Standards/Documents/Scope\%20of\%20Practice\%20September\%202013 \%20(3)pdf. 2013;Accessed 23/09/2013.

35. British Society of Periodontology. BASIC PERIODONTAL EXAMINATION (BPE).

http://wwwbsperioorguk/publications/downloads/39_143748_bpe2011pdf. 2011;Accessed 28

March 2013.

36. Morse JM. The significance of saturation. Qualitative Health Research. 1995;5(2):147-9.

37. Pope C, Ziebland S, Mays N. Qualitative research in health care Analysing qualitative data. BMJ. 2003;320:114 - 6.

38. Mays N, Pope C. Qualitative research in health care: assessing quality in qualitative research. BMJ. 2000;320(7226):50.

39. Macey R, Glenny A, Walsh T, Tickle M, Worthington H, Ashley J, et al. The Efficacy of Screening for Common Dental Diseases by Hygiene-Therapists A Diagnostic Test Accuracy Study. Journal of Dental Research. 2015;94(3):70S-8S.

40. Bower P, Brueton V, Gamble C, Treweek S, Smith CT, Young B, et al. Interventions to improve recruitment and retention in clinical trials: a survey and workshop to assess current practice and future priorities. Trials. 2014;15(1):399.

41. Treweek S, Lockhart P, Pitkethly M, Cook JA, Kjeldstrøm M, Johansen M, et al. Methods to improve recruitment to randomised controlled trials: Cochrane systematic review and meta-analysis. BMJ Open. 2013;3(2):e002360.

42. Reekie $D$, Devlin $\mathrm{H}$, Worthington $\mathrm{H}$. The prevention of failed appointments in general dental practice. British Dental Journal. 1997;182(4):139-43. 
43. Brocklehurst P, Pemberton M, Macey R, Cotton C, Walsh T, Lewis M. Comparative accuracy of different members of the dental team in detecting malignant and non-malignant oral lesions. British Dental Journal. 2015;218(9):525-9.

44. Phillips E, Shaefer HL, Aksu MN, Lapidos A. Is a mid-level dental provider model acceptable to potential patients? Community dentistry and oral epidemiology. 2016. 
Table 1: Results of recruitment rate and different recruitment methods

\begin{tabular}{|l|c|c|c|}
\hline $\begin{array}{l}\text { Recruitment } \\
\text { method }\end{array}$ & $\begin{array}{c}\text { Practice 1 } \\
\text { Recruitment } \\
\text { Rate }\end{array}$ & $\begin{array}{c}\text { Practice 2 } \\
\text { Recruitment } \\
\text { Rate }\end{array}$ & $\begin{array}{c}\text { Total } \\
\text { Recruitment Rate }\end{array}$ \\
\hline Letters & $3 / 63(5 \%)$ & $0 / 40(0 \%)$ & $3 / 110(2.72 \%)$ \\
\hline $\begin{array}{l}\text { Telephone } \\
\text { calls }\end{array}$ & $27 / 29(93 \%)$ & $7 / 11(64 \%)$ & $34 / 40(85.0 \%)$ \\
\hline Face-to-face & $0 / 0(0 \%)$ & $23 / 28(82 \%)$ & $23 / 28(82.14 \%)$ \\
\hline $\begin{array}{l}\text { Total } \\
\text { recruited }\end{array}$ & $30 / 92(33 \%)$ & $30 / 86(35 \%)$ & $60 / 178(33.71 \%)$ \\
\hline
\end{tabular}

Table 2: Results of retention of patients

\begin{tabular}{|l|l|l|}
\hline & $\begin{array}{l}\text { Retention at } \\
\text { Appointment 2 }\end{array}$ & $\begin{array}{l}\text { Retention at } \\
\text { Appointment 3 }\end{array}$ \\
\hline Arm 1: H-T only & $15 / 20(75.0 \%)$ & $12 / 20(60.0 \%)$ \\
\hline $\begin{array}{l}\text { Arm 2: GDP / H-T } \\
\text { (alternate) }\end{array}$ & $14 / 20(70.0 \%)$ & $12 / 20(60.0 \%)$ \\
\hline Arm 3: GDP only & $18 / 20(90.0 \%)$ & $14 / 20(70.0 \%)$ \\
\hline Overall & $47 / 60(78.3 \%)$ & $38 / 60(63.3 \%)$ \\
\hline
\end{tabular}


Table 3: Results of fidelity

\begin{tabular}{|l|c|c|c|}
\hline & $\begin{array}{c}\text { Fidelity } \\
\text { Appointment 1 }\end{array}$ & $\begin{array}{c}\text { Fidelity } \\
\text { Appointment 2 }\end{array}$ & $\begin{array}{c}\text { Fidelity } \\
\text { Appointment 3 }\end{array}$ \\
\hline Practice 1 & $30 / 30(100 \%)$ & $24 / 24(100 \%)$ & $17 / 18(94.44 \%)$ \\
\hline Practice 2 & $30 / 30(100 \%)$ & $22 / 23(95.65 \%)$ & $19 / 20(95 \%)$ \\
\hline Overall & $60 / 60(100 \%)$ & $46 / 47(97.79 \%)$ & $36 / 38(94.74 \%)$ \\
\hline
\end{tabular}


Table 4: Proportion of sites with bleeding on probing (BoP), plaque, pocketing (greater than $3.5 \mathrm{~mm}$ ), caries across the three arms of the study

\begin{tabular}{|c|c|c|c|}
\hline & $\begin{array}{l}\text { Arm 1: } \\
\text { H-T only }\end{array}$ & $\begin{array}{l}\text { Arm 2: } \\
\text { GDP then H-T } \\
\text { (alternate) }\end{array}$ & $\begin{array}{l}\text { Arm 3: } \\
\text { GDP only }\end{array}$ \\
\hline \multicolumn{4}{|c|}{ Proportion of sites with BoP (\%) } \\
\hline $\begin{array}{l}\text { Appointment 1: } \\
\text { Baseline }\end{array}$ & \begin{tabular}{|l}
$213 / 478$ \\
$(44.56)$
\end{tabular} & \begin{tabular}{|l|}
$87 / 506$ \\
$(17.19)$
\end{tabular} & \begin{tabular}{|l}
$142 / 535$ \\
$(26.54)$
\end{tabular} \\
\hline $\begin{array}{l}\text { Appointment 2: } \\
\text { Follow up }\end{array}$ & $\begin{array}{l}162 / 406 \\
(39.90)\end{array}$ & $\begin{array}{l}122 / 312 \\
(39.10)\end{array}$ & $\begin{array}{l}129 / 486 \\
(26.54)\end{array}$ \\
\hline $\begin{array}{l}\text { Appointment 3: } \\
\text { Outcome }\end{array}$ & $\begin{array}{l}136 / 291 \\
(46.74)\end{array}$ & $\begin{array}{l}69 / 284 \\
(14.45)\end{array}$ & $\begin{array}{l}119 / 371 \\
(32.08)\end{array}$ \\
\hline \multicolumn{4}{|c|}{ Proportion of sites with plaque (\%) } \\
\hline $\begin{array}{l}\text { Appointment 1: } \\
\text { Baseline }\end{array}$ & \begin{tabular}{|l}
$289 / 478$ \\
$(60.46)$
\end{tabular} & $\begin{array}{l}227 / 506 \\
(44.86)\end{array}$ & $\begin{array}{l}301 / 535 \\
(56.26)\end{array}$ \\
\hline $\begin{array}{l}\text { Appointment 2: } \\
\text { Follow up }\end{array}$ & $\begin{array}{l}196 / 406 \\
(48.28)\end{array}$ & $\begin{array}{l}146 / 312 \\
(46.79)\end{array}$ & $\begin{array}{l}217 / 486 \\
(44.65)\end{array}$ \\
\hline $\begin{array}{l}\text { Appointment 3: } \\
\text { Outcome }\end{array}$ & $\begin{array}{l}197 / 291 \\
(68.17)\end{array}$ & $\begin{array}{l}124 / 284 \\
(43.67)\end{array}$ & $\begin{array}{l}226 / 371 \\
(60.92)\end{array}$ \\
\hline \multicolumn{4}{|c|}{ Proportion of sites with pocketing (\%) } \\
\hline $\begin{array}{l}\text { Appointment 1: } \\
\text { Baseline }\end{array}$ & \begin{tabular}{|l}
$55 / 478$ \\
$(12.04)$
\end{tabular} & \begin{tabular}{|l}
$53 / 506$ \\
$(10.06)$
\end{tabular} & $\begin{array}{l}97 / 535 \\
(18.13)\end{array}$ \\
\hline $\begin{array}{l}\text { Appointment 2: } \\
\text { Follow up }\end{array}$ & $\begin{array}{l}52 / 406 \\
(12.81)\end{array}$ & $\begin{array}{l}29 / 312 \\
(9.29)\end{array}$ & $\begin{array}{l}90 / 486 \\
(18.52)\end{array}$ \\
\hline $\begin{array}{l}\text { Appointment 3: } \\
\text { Outcome }\end{array}$ & $\begin{array}{l}67 / 291 \\
(23.02)\end{array}$ & $\begin{array}{l}31 / 284 \\
(10.92)\end{array}$ & $\begin{array}{l}90 / 371 \\
(24.26)\end{array}$ \\
\hline \multicolumn{4}{|c|}{ Proportion of sites with caries (\%) } \\
\hline $\begin{array}{l}\text { Appointment 1: } \\
\text { Baseline }\end{array}$ & $\begin{array}{l}11 / 478 \\
(2.30)\end{array}$ & \begin{tabular}{|l}
$6 / 506$ \\
$(1.19)$
\end{tabular} & $\begin{array}{l}14 / 535 \\
(2.62)\end{array}$ \\
\hline $\begin{array}{l}\text { Appointment 2: } \\
\text { Follow up }\end{array}$ & $\begin{array}{l}4 / 406 \\
(0.99)\end{array}$ & $\begin{array}{l}5 / 312 \\
(1.60)\end{array}$ & $\begin{array}{l}9 / 486 \\
(1.85)\end{array}$ \\
\hline $\begin{array}{l}\text { Appointment 3: } \\
\text { Outcome }\end{array}$ & $\begin{array}{l}5 / 291 \\
(1.72)\end{array}$ & \begin{tabular}{|l|}
$4 / 284$ \\
$(1.41)$
\end{tabular} & $\begin{array}{l}7 / 371 \\
(1.89)\end{array}$ \\
\hline
\end{tabular}


Table 5: Coding frame

\begin{tabular}{|c|c|c|}
\hline Themes & Codes & Example \\
\hline \multirow{7}{*}{$\begin{array}{l}\text { 1. Beliefs of } \\
\text { patient which } \\
\text { inform } \\
\text { acceptance of } \\
\text { H-T }\end{array}$} & (a) H-T skill level & $\begin{array}{l}\text { "[they] know what they're doing. That's } \\
\text { the main thing" }\end{array}$ \\
\hline & (b) $\mathrm{H}-\mathrm{T}$ qualities & $\begin{array}{l}\text { "I just feel...A bit more relaxed, yes, } \\
\text { because you think well, this isn't the } \\
\text { dentist who's going to drill. It's a bit } \\
\text { more, yeah, at ease" }\end{array}$ \\
\hline & (c) Trust in system & $\begin{array}{l}\text { "I sort of hoped that the system or the } \\
\text { therapist themselves would know } \\
\text { whether it's going to be something that's } \\
\text { in their capability" }\end{array}$ \\
\hline & (d) Trust in practice & $\begin{array}{l}\text { "If I come to this practice I put my faith in } \\
\text { them because they are doing my teeth a } \\
\text { great" }\end{array}$ \\
\hline & $\begin{array}{l}\text { (e) Comparison to } \\
\text { medicine - embracing } \\
\text { teamwork }\end{array}$ & $\begin{array}{l}\text { "the nurses do a lot of... practice nurse } \\
\text { do some of the treatments. And, I think } \\
\text { that this is what they're talking about" }\end{array}$ \\
\hline & $\begin{array}{l}\text { (f) Training } \\
\text { explanation/ } \\
\text { acceptance }\end{array}$ & $\begin{array}{l}\text { "he explained that they are properly } \\
\text { qualified, that the people who are doing } \\
\text { the check-ups are qualified" }\end{array}$ \\
\hline & $\begin{array}{l}\text { (g) See benefit in role } \\
\text { substitution }\end{array}$ & $\begin{array}{l}\text { "it, sort of, takes the pressure off the } \\
\text { dentist and leaves them to do the dental } \\
\text { work... I think it's a great idea" }\end{array}$ \\
\hline \multirow[t]{4}{*}{$\begin{array}{l}\text { 2. Impact of } \\
\text { patient } \\
\text { involvement in } \\
\text { study }\end{array}$} & $\begin{array}{l}\text { (h) Patient experience } \\
\text { - trust in } \mathrm{H}-\mathrm{T}\end{array}$ & $\begin{array}{l}\text { "the dentist came out and explained to } \\
\text { the therapist...so the therapist is learning } \\
\text { from the dentist..... I wouldn't put trust } \\
\text { on a therapist at this point in time" }\end{array}$ \\
\hline & $\begin{array}{l}\text { (i) Positive feedback } \\
\text { on H-T check up }\end{array}$ & $\begin{array}{l}\text { "I may have had some reservations } \\
\text { maybe before l'd seen the therapist, but } \\
\text { have been very happy" }\end{array}$ \\
\hline & $\begin{array}{l}\text { (j) Which is the best } \\
\text { method, GDP only, H- } \\
\text { T only, alternate }\end{array}$ & $\begin{array}{l}\text { "I suppose in the perfect world, you } \\
\text { know, a mix of both would be good, but } \\
\text { I've sort of got faith in the system that } \\
\text { whether seeing the dentist or therapist" }\end{array}$ \\
\hline & $\begin{array}{l}\text { (k) Difference in } \\
\text { payment - are dentists } \\
\text { worth more? }\end{array}$ & $\begin{array}{l}\text { "doesn't make any difference.... If you're } \\
\text { getting the same treatment by } \\
\text { somebody that's qualified I really don't } \\
\text { see what difference it makes" }\end{array}$ \\
\hline \multirow[t]{2}{*}{$\begin{array}{l}\text { 3. Patient's } \\
\text { preferences }\end{array}$} & (I) Prefer H-T or GDP & $\begin{array}{l}\text { "I don't care as long as they do the job } \\
\text { and do what is good for me or whatever } \\
\text { I'm not bothered" }\end{array}$ \\
\hline & $\begin{array}{l}\text { (m) Seeks consistency } \\
\text { in practitioner }\end{array}$ & $\begin{array}{l}\text { "I think if you were seeing a different one } \\
\text { every single time and you're having to } \\
\text { go through, you'd probably lack a bit of } \\
\text { confidence" }\end{array}$ \\
\hline
\end{tabular}



